\title{
DETERMINAN PRODUKTIVITAS LAHAN PERTANIAN SUBSEKTOR TANAMAN PANGAN DI INDONESIA
}

\author{
Fazriyan Wardani Adhitya 1, Djoni Hartono 2, dan Agni Alam Awirya ${ }^{3}$ \\ ${ }^{1}$ Dinas Perikanan dan Kelautan Kabupaten Karawang \\ Jalan Ir. Suratin No. 1 Karawang Jawa Barat, Telepon +6285781459011 \\ 2 Departemen Ilmu Ekonomi, Fakultas Ekonomi, Universitas Indonesia \\ Kampus Universitas Indonesia Depok, 16424, Telepon+628161189299 \\ ${ }^{3}$ Divisi Ekonomi Moneter, Kantor Perwakilan Bank Indonesia Wilayah III \\ Jalan Letda Tantular no 4, Denpasar, Telepon +6281808309726 \\ E-mail: ryan.aditkrw@gmail.com
}

Diterima 14 Juli 2012 / Disetujui 3 April 2013

\begin{abstract}
This study is aimed to analyze the determinant factors affecting the agricultural land productivity of food crops sub-sectors in 25 provinces in Indonesia during the period of 2005-2009. Descriptive analysis is done to describe the agricultural land productivity of food crops sub-sectors in Indonesia. The Cobb-Douglas production function with the assumption of Constant Return to Scale on the food crops sub-sectors production is applied. To solve the heteroschedasticity problems and avoid the auto-correlation, then the Generalized Least Square estimator with Cross-Section Weight is done. The result shows that labors and fertilizer are two factors that do not affect significantly to the productivity of food crops sub-sectors; while capital, research, human resources and irrigation are factors that affect positively to the agricultural land productivity of food crops sub-sectors. The study also shows Java as the area with the highest level of productivity and Maluku has the lowest level of productivity.
\end{abstract}

Keywords: Agriculture, Food Crops, Land Productivity, production function

\begin{abstract}
Abstrak: Studi ini bertujuan mengkaji faktor-faktor yang dapat mempengaruhi produktifitas lahan pertanian sub-sektor tanaman pangan di 25 provinsi di Indonesia, selama kurun waktu 2005-2009. Analisis deskriptif dilakukan untuk menggambarkan produktifitas lahan pertanian sub-sektor tanaman pangan di Indonesia. Fungsi produksi Cobb-Gouglas diterapkan dengan asumsi Constant Return to Scale pada produksi pertanian sub-sektor tanaman pangan. Penerapan estimator Generalized Least Square dengan Cross-Section Weight dilakukan guna mengatasi masalah heteroskedastisitas dan auto-korelasi. Hasil menunjukkan faktor tenaga kerja dan penggunaan pupuk tidak memberikan pengaruh yang signifikan terhadap produktifitas lahan pertanian sub-sektor tanaman pangan; sedangkan faktor modal, riset dan pengembangan pertanian, kualitas sumber daya manusia, dan irigasi memberikan pengaruh positif terhadap produktifitas lahan pertanian sub-sektor tanaman pangan. Diketahui pula Jawa sebagai daerah dengan tingkat produktifitas tertinggi dan Maluku memiliki tingkat produktifitas terendah.
\end{abstract}

Kata kunci: pertanian, tanaman pangan, produktiviras lahan, fungsi produksi

\section{PENDAHULUAN}

Indonesia sebagai salah satu negara berkembang mempunyai salah satu ciri jumlah penduduk yang besar. Data statistik dari Badan Pusat
Statistik (BPS) menunjukkan perkembangan jumlah penduduk Indonesia tahun 1995 sebesar 194,75 juta orang yang semakin meningkat pada tahun 2004 sebesar 216,38 juta orang, maka laju pertumbuhan penduduknya per 
tahun sebesar 1,18 persen (BPS, 2005). Sedangkan perkembangan lahan tanaman pangan sebagai sarana produksi yang terdiri dari lahan sawah dan lahan kering pada tahun 1995 sebesar 10,42 juta hektar dan berubah menjadi 10,99 juta hektar pada tahun 2004, sehingga laju pertumbuhannya per tahun sebesar 0,60 persen. Bila kondisi tersebut terjadi pada tahun berikutnya dikhawatirkan kebutuhan pangan di Indonesia pada masa yang akan datang tidak akan terpenuhi. Oleh karena perlu dilakukan upaya peningkatan produksi pertanian termasuk meningkatkan produktivitas pertanian.

Daniel (2004) menyebutkan bahwa upaya peningkatan output produksi pertanian dapat dipengaruhi oleh faktor-faktor input produksi pertanian seperti tenaga kerja, modal, dan lahan dan manajemen usaha. Masing-masing faktor mempunyai fungsi yang berbeda dan saling terkait satu sama lain. Teknologi juga berperan dalam menentukan saling keterkaitan antarfaktor produksi. Misalnya bila seseorang akan mengupayakan usaha tanaman pangan seluas satu hektar bagaimana menentukan jumlah modal dan tenaga kerja yang dibutuhkan, dapat ditentukan dengan menetapkan teknologi yang akan diterapkan.

Salah satu faktor yang penting dalam peningkatan produktivitas lahan pertanian komoditas tanaman pangan adalah pengelolaan lahan. Wiebe (2003) menyatakan bahwa produktivitas pertanian sangat penting dalam menciptakan ketahanan pangan dan lahan sangat berpengaruh dalam peningkatan produktivitas pertanian.

Faktor lain yang cukup penting dalam menunjang peningkatan produktivitas lahan pertanian tanaman pangan di pedesaan adalah infrastruktur. Evenson and Pray (1991) menyebutkan infrastruktur sebagai salah satu faktor tetap yang berkontribusi positif terhadap pertumbuhan sektor pertanian dan produktivitasnya. Salah satu infrastruktur yang menunjang sektor pertanian tanaman pangan adalah irigasi.

Salah satu bentuk kebijakan pemerintah dalam upaya peningkatan produksi tanaman pangan adalah kebijakan subsidi harga pupuk. Pembelian pupuk urea yang murah mengakibatkan petani menggunakan input produksi pupuk semakin banyak. Irawan dkk (2003) yang telah mengkaji faktor penyebab perlambatan produktivitas usaha komoditas padi sebagai bagian komoditas tanaman pangan utama dikarenakan tidak adanya terobosan teknologi padi secara signifikan. Penelitian tersebut juga menemukan masih banyak petani yang menggunakan pupuk urea melebihi standar pemakaian per hektarnya, karena para petani berpikir semakin banyak pupuk urea yang digunakan maka hasil panen padi akan semakin meningkat. Padahal penggunaan dosis pupuk yang berlebihan dapat menyebabkan penurunan kualitas tanah.

Faktor lain yang tidak kalah penting memengaruhi produktivitas lahan pertanian tanaman pangan adalah tenaga kerja. Namun peningkatan jumlah tenaga kerja yang melimpah jika tidak disertai kualitas tenaga kerja yang memadai akan menyebabkan dampak produktivitas yang negatif. Proporsi tenaga kerja di Indonesia khususnya di Pulau Jawa terutama pada agroekosistem lahan sawah relatif terdistribusi lebih merata antarkelompok umur, dibandingkan dengan di luar Jawa yang lebih banyak dilakukan pekerja muda (Susilowati dkk, 2008). Berdasarkan data Survei Sosial Ekonomi Nasional BPS, sektor pertanian merupakan salah satu sektor ekonomi yang mampu menyerap tenaga kerja Indonesia dalam jumlah yang besar dari tahun 2005-2009, namun demikian tenaga kerja yang bekerja pada sektor pertanian tanaman pangan di pedesaan cenderung mengalami penurunan dari 19,37 juta orang menjadi 18,335 juta orang (BPS-Kementerian Pertanian, 2010).

Faktor terakhir yang penting dalam meningkatkan produktivitas lahan pertanian tanaman pangan adalah modal. Istilah modal dalam usaha pertanian mencakup alat-alat pertanian, bibit, pestisida, traktor dan sarana fisik lain yang menunjang produksi pertanian tanaman pangan. Biasanya petani memperoleh modal baik melalui pemberian kredit perbankan maupun pinjaman dari keluarganya yang cenderung lebih mudah prosesnya daripada proses perbankan. Pemerintah telah membantu petani untuk memperoleh modal dari sejak program Bimas/Inmas tahun 1976-1984. Namun pada periode tersebut terjadi peman- 
degan karena tunggakan semakin banyak dan petani cenderung tidak mampu membayar kembali. Program pemberian kredit untuk pertanian mulai tahun 2000 diberikan melalui perbankan dengan nama kredit ketahanan pangan dengan perkembangan yang cenderung meningkat (Bank Indonesia, 2010).

Penelitian determinan produktivitas lahan pertanian khususnya komoditas tanaman pangan masih relevan dilakukan. Penelitian ini akan menganalisis secara dreskiptif gambaran produktivitas lahan pertanian subsektor tanaman pangan di Indonesia. Penelitian ini akan mendasarkan analisisnya pada hipotesis bahwa diduga modal, tenaga kerja, riset dan pengembangan pertanian, lahan yang teraliri irigasi, penggunaan pupuk urea, dan rata-rata lama sekolah petani berpengaruh positif terhadap produktivitas lahan pertanian subsektor tanaman pangan. Oleh karena itu, penelitian ini juga akan mengkaji faktor-faktor apa saja yang dapat memengaruhi produktivitas lahan pertanian subsektor tanaman pangan di Indonesia.

Studi Literatur. Kebanyakan penelitian produktivitas lahan dengan menggunakan pendekatan fungsi produksi Cobb Douglas. Secara umum faktor yang dapat memengaruhi produktivitas lahan pertanian adalah semua variabel penjelas input yang lainnya selain lahan. Piya, Kiminami dan Yagi (2011) mengkaji produktivitas lahan pertanian di Asia Selatan dan Asia Tenggara. Hasil risetnya menemukan faktor-faktor yang memengaruhi produktivitas lahan pertanian adalah variabel pupuk/hektar yang berpengaruh positif dengan elastisitas 0,21, demikian juga variabel traktor/hektar berpengaruh positif dengan elastisitas 0,12 , dan variabel ternak/hektar berpengaruh positif dengan elastisitas 0,36 serta tenaga kerja/hektar juga berpengaruh positif terhadap produktivitas lahan dengan elastisitas 0,40 yang juga merupakan pengaruh terbesar dalam mempengaruhi produktivitas lahan pertanian. Sedangkan sumber pertumbuhan produksi pertanian lebih dominan kontribusi dari produktivitas lahan daripada kontribusi perluasan lahan.

Iqbal, Ahmad, and Abbas (2003) mengkaji dampak kredit terhadap produktivitas lahan pertanian di Pakistan, kemudian mengestimasi fungsi produktivitas lahan pertanian dengan pendekatan variabel dependennya PDB pertanian per hektar dikarenakan pertanian merupakan multioutput produk yang terdiri dari tanaman pangan, hortikultur, perkebunan, peternakan, kehutanan, dan perikanan. Hasil penelitiannya menemukan bahwa kredit, jumlah tenaga kerja, luas lahan teririgasi mempengaruhi produktivitas lahan pertanian.

Masterson (2007) melakukan penelitian produktivitas lahan, efisiensi teknis dan skala ukuran tanaman pangan pada sektor pertanian di Paraguay. Hasil penelitiannya dengan menggunakan model regresi berganda ditemukan variabel luas lahan yang dikuasai berpengaruh negatif terhadap produktivitas lahan. Sedangkan ukuran rumah tangga, asset, akses kredit, bantuan teknologi, dan kualitas tanah berpengaruh positif terhadap produktivitas lahan pertanian.

Thirtle, Lin dan Piesse (2003) juga mengkaji produktivitas lahan pertanian dengan tujuan mengetahui dampak riset pertanian terhadap pertumbuhan produktivitas lahan pertanian yang akhirnya berdampak terhadap pengurangan kemiskinan di Afrika, Asia, dan Amerika Latin. Riset dan pengembangan pertanian akan berdampak terhadap produktivitas lahan pertanian tanaman pangan melalui timbulnya inovasi varietas baru yang menghasilkan output lebih banyak lagi, penggunaan pupuk dan pestisida menjadi lebih efektif, pembenihan peternakan lebih praktis dan produktif. Penelitian dan pengembangan pertanian dibutuhkan tidak hanya untuk meningkatkan produktivitas tanaman pangan, tetapi juga untuk menjaga agar produktivitas tanaman tetap terkontrol dengan semakin berkembangnya berbagai macam penyakit dan hama pada tanaman pangan yang semakin bervariasi.

Gaiha and Imai (2008) mengkaji determinan pertumbuhan pertanian, determinan tenaga kerja pertanian dan tingkat upah di negaranegara berkembang. Hasil penelitiannya ditemukan bahwa mesin traktor, lahan yang teririgasi, penggunaan pupuk, tenaga kerja pertanian berpengaruh positif terhadap produktivitas lahan pertanian. 


\section{METODE PENELITIAN}

\section{Strategi Analisis Data}

Analisis data dibagi menjadi dua bagian yaitu analisis deskriptif dan analisis inferensial. Analisis deskriptif digunakan sebagai penduga awal hubungan antarvariabel. Dengan demikian, hasil analisis deskriptif juga menjadi media konfirmasi hasil estimasi inferensial guna menguji kekuatan model yang digunakan. Analisis deskriptif dilakukan pada hubungan antar variabel dalam bentuk diagram titik.

\section{Model Penelitian}

Penelitian ini menerapkan fungsi produksi Cobb-Douglas dengan asumsi Constant Return to Scale (CRS) pada produksi pertanian subsektor tanaman pangan. Pengembangan fungsi produksi Cobb-Douglas dilakukan dengan menambah jumlah input dari 2 (modal dan tenaga kerja) menjadi 7 input, sehingga fungsi produksi berbentuk sebagai berikut:

$Y=$

A. $L H N^{\alpha 1} \cdot T K^{\alpha 2} \cdot M D L^{\alpha 3} \cdot R I S^{\alpha 4} \cdot P U P^{\alpha 5} \cdot S D M^{\alpha 6} \cdot I R D^{\alpha 7}$

dimana $\mathrm{Y}$ adalah output, A adalah total factor productivity, LHN adalah luas lahan pertanian tanaman pangan, TK adalah tenaga kerja pertanian tanaman pangan, MDL adalah modal pertanian tanaman pangan, RIS adalah riset dan pengembangan pertanian tanaman pangan, PUP adalah pupuk pertanian tanaman pangan, SDM adalah sumber daya manusia/kualitas pada pekerja pertanian tanaman pangan dan IRD adalah luas lahan pertanian tanaman pangan teririgasi. Persamaan 1 diubah ke dalam bentuk logaritma natural pada kedua sisi menjadi:

$$
\begin{aligned}
\operatorname{Ln}\left(\frac{Y}{L H N}\right)= & \operatorname{Ln}(A)+\alpha_{2} \operatorname{Ln}\left(\frac{T K}{L H N}\right)+ \\
& \alpha_{3} \operatorname{Ln}\left(\frac{M D L}{L H N}\right)+\alpha_{4} \operatorname{Ln}\left(\frac{R I S}{L H N}\right)+ \\
& \alpha_{5} \operatorname{Ln}\left(\frac{P U P}{L H N}\right)+\alpha_{6} \operatorname{Ln}\left(\frac{S D M}{L H N}\right)+ \\
& \alpha_{7} \operatorname{Ln}\left(\frac{I R D}{L H N}\right)
\end{aligned}
$$

Sisi sebelah kiri, $\frac{y}{L H N}$, dapat dibaca sebagai produktivitas lahan pertanian tanaman pangan. Sedangkan rasio pada sisi sebelah kanan, 6 komponen terakhir menunjukkan rasio antara salah satu input terhadap input tertentu. Rasio tersebut dapat dibaca sebagai intensitas, misalnya pada fungsi produksi Cobb-Douglass, $\mathrm{K} / \mathrm{L}$ dapat dibaca sebagai intensitas penggunaan modal. Dengan demikian pada persamaan $2\left(\frac{Y}{L H N}\right)$ adalah produktivitas lahan pertanian tanaman pangan, $\left(\frac{T K}{L H N}\right)$ adalah intensitas penggunaan tenaga kerja pertanian tanaman pangan, $\left(\frac{M D L}{L H N}\right)$ adalah intensitas penggunaan modal pertanian tanaman pangan, $\left(\frac{R I S}{L H N}\right)$ adalah intensitas penggunaan riset pertanian tanaman pangan, $\left(\frac{P U P}{L H N}\right)$ adalah intensitas penggunaan pupuk pertanian tanaman pangan, $\left(\frac{S D M}{L H N}\right)$ adalah intensitas kualitas tenaga kerja pada pekerja pertanian tanaman pangan dan $\left(\frac{I R D}{L H N}\right)$ adalah intensitas lahan pertanian tanaman pangan teririgasi.

Penerapan hasil riset membutuhkan jeda waktu karena penelitian yang dilakukan tidak langsung dapat diterapkan di lapangan. Panjang jeda waktu optimal ditentukan dari uji statistik. Perbedaan infrastruktur antarwilayah akan dikontrol dengan variabel dummy. Berdasarkan persamaan 2 bentuk persamaan regresi yang digunakan dalam penelitian ini berbentuk:

$$
\begin{aligned}
\operatorname{Ln}\left(\text { PRODV }_{i t}\right) & =\beta_{0}+\beta_{1} \operatorname{Ln}\left(\text { TKL }_{i t}\right)+ \\
& \beta_{2} \operatorname{Ln}\left(\text { MODAL }_{i t}\right)+\beta_{3} \operatorname{Ln}\left(\operatorname{RISET}_{i(t-2)}\right)+ \\
& \beta_{4} \operatorname{Ln}\left(\text { PUPUK }_{i t}\right)+\beta_{5} \operatorname{Ln}\left(\operatorname{SDML}_{i t}\right)+ \\
& \beta_{5} \operatorname{Ln}\left(\text { IRIGASI }_{i t}\right) \\
& + \text { DInf }+\varepsilon_{i t}
\end{aligned}
$$

dimana $\mathrm{PRODV}_{\text {it }}$ adalah produktivitas lahan pertanian tanaman pangan, TKL $\mathrm{L}_{\text {it }}$ adalah intensitas penggunaan tenaga kerja pertanian tanaman pangan, MODAL $L_{i t}$ adalah intensitas penggunaan modal pertanian tanaman pangan, RISET $_{\text {it }}$ adalah intensitas penggunaan riset penelitian dan pengembangan pertanian tanaman pangan, PUPUK $_{\text {it }}$ adalah intensitas penggunaan pupuk pertanian tanaman pangan, SDMLit adalah intensitas kualitas tenaga kerja pertanian tanaman pangan, IRIGASI ${ }_{i t}$ adalah intensitas penggunaan lahan pertanian tanaman pangan yang teririgasi, DInf adalah variabel dummy 
infrastruktur irigasi dengan nilai 1 untuk kategori infrastruktur irigasi baik, dan bernilai 0 untuk kategori infrastruktur irigasi tidak baik, dan $\varepsilon$ adalah error term.

\section{Data dan Sumber Data}

Data modal (MDL) pertanian tanaman pangan menggunakan data nilai kredit. Karena keterbatasan data, modal yang digunakan dalam penelitian ini dengan pendekatan nilai kredit yang diberikan oleh Bank Umum dan Bank BPR berupa modal kerja pertanian secara umum, bukan modal kerja pertanian tanaman pangan. Data modal dalam penelitian ini belum mencerminkan capital stock.

Data riset dan pengembangan pertanian tanaman pangan (RIS) menggunakan data anggaran penelitian dan pengembangan pertanian. Karena keterbatasan data, anggaran penelitian dan pengembangan pertanian pada Balai Pengkajian Teknologi Pertanian (BPTP), Badan Penelitian dan Pengembangan Pertanian, Kementerian Pertanian.

Data sumber daya manusia (SDM) menggunakan data rata-rata lama sekolah pada pekerja pertanian tanaman pangan. Alasannya, kualitas tenaga kerja merupakan sesuatu yang abstrak. Maka didekati dengan data rata-rata lama sekolah pada pekerja pertanian usia 15 tahun keatas. Data yang akan digunakan dalam penelitian ini adalah data sekunder dari BPS, Kementerian Pertanian dan Bank Indonesia.

Wilayah observasi penelitian mencakup seluruh provinsi di Indonesia dengan beberapa penggabungan pada provinsi yang berdekatan. Penggabungan tersebut antara lain Riau digabung dengan Kepulauan Riau, Jawa Tengah digabung Daerah Istimewa Yogyakarta (DIY), Bali digabung Nusa Tenggara Barat (NTB) serta Nusa Tenggara Timur (NTT), Sulawesi Selatan digabung dengan Sulawesi Barat, Maluku digabung dengan Maluku Utara dan Papua digabung dengan Papua Barat. Wilayah Provinsi DKI Jakarta tidak dimasukkan ke dalam penelitian. Alasannya, cakupan penelitian ini adalah pertanian tanaman pangan di pedesaan saja.

Periode waktu yang digunakan dalam penelitian ini adalah dari tahun 2005-2009. Menurut Wooldridge (2009) menyebutkan bah- wa data panel merupakan data kombinasi antara data runtut waktu (time series) dengan data kerat lintang antarindividu (cross-section). Ciri khusus runtut waktu adalah berupa urutan numerik dimana interval antarobservasi atas sejumlah variabel bersifat konstan dan tetap. Sedangkan data kerat lintang adalah suatu unit analisis pada suatu titik waktu tertentu dengan observasi atas sejumlah variabel.

\section{HASIL DAN PEMBAHASAN}

Pada usaha pertanian banyak variabel yang tidak terobservasi dapat mempengaruhi produktivitas lahan pertanian tanaman pangan, namun juga dapat memengaruhi variabel penjelas misalnya kualitas lahan dan jumlah curah hujan. Sementara penelitian ini mengasumsikan bahwa strict exogeneity explanatory variabels conditional on unobservables (Wooldridge, 2002). Maka model yang terbaik untuk mengestimasi terhadap persamaan model 3 adalah fixed effect.

Penelitian ini menggunakan asumsi terjadi adanya masalah heteroskedastisitas pada data karena data ekonomi mikro cenderung heteroskedastis. Masalah heteroskedastisitas dapat diatasi menggunakan estimator GLS dengan cross-section weight (Wooldridge, 2009). Dampak lain penggunaan estimator GLS adalah mengatasi masalah autokorelasi.

\section{Analisis Deskriptif}

Analisis hubungan antara variabel yang dijelaskan dengan masing masing variabel penjelasnya digambarkan secara grafis. Analisis hubungan antara variabel ini tidak menggambarkan kausalitas. Gambar 1 menunjukkan gambaran hubungan antara rata-rata produktivitas lahan pertanian tanaman pangan dengan intensitas penggunaan tenaga kerja rata-rata di 25 provinsi selama periode 2005-2009. Bila dianalisis lebih dalam hubungan antara laju rata-rata pertumbuhan jumlah tenaga kerja dan laju rata-rata pertumbuhan produktivitas lahan pertanian tanaman pangan untuk wilayah Jawa dan Sumatera terdapat 61,5 persen dari 13 wilayah provinsi tersebut mempunyai anomali hubungan antara laju rata-rata pertumbuhan 
tenaga kerja dengan laju rata-rata pertumbuhan produktivitas lahan selama 2005-2009 yakni Provinsi Sumatera Selatan, Bengkulu, Lampung, Bangka Belitung, Jawa Barat, Jawa Tengah digabung DIY, Jawa Timur, dan Banten. Wilayah tersebut menggambarkan penurunan rata-rata pertumbuhan jumlah tenaga kerja yang tidak seiring dengan peningkatan ratarata pertumbuhan produktivitas lahan. Hal tersebut dimungkinkan untuk wilayah tersebut sudah mengalami surplus tenaga kerja. Artinya walaupun terjadi penurunan tenaga kerja tanaman pangan, namun produktivitas lahan tanaman pangan tetap mengalami pertumbuhan yang meningkat. Sedangkan bila dianalisis untuk wilayah Provinsi Bali, NTB, NTT, Kalimantan, Sulawesi dan Papua ditemukan sekitar 58,3 persen dari 12 wilayah tersebut tidak mengalami anomali hubungan antara laju rata-rata pertumbuhan tenaga kerja dengan laju rata-rata pertumbuhan produktivitas lahan yakni Provinsi Kalimantan Barat, Kalimantan Tengah, Kalimantan Timur, Sulawesi Utara, Sulawesi Tengah, Sulawesi Tenggara, dan Papua digabung Papua Barat. Wilayah tersebut menggambarkan peningkatan rata-rata pertumbuhan jumlah tenaga kerja seiring dengan peningkatan rata-rata pertumbuhan produktivitas lahan. Artinya peningkatan pertumbuhan jumlah tenaga kerja di wilayah Kawasan Timur Indonesia (Sulawesi, Papua, NTB, NTT, serta Kalimantan) masih kebanyakan disertai peningkatan pertumbuhan produktivitas lahannya.

Perkembangan produktivitas lahan pertanian pada tahun 2005 terdapat tiga wilayah yang memiliki produktivitas lahan tertinggi yakni Provinsi Jawa Tengah digabung DIY, Jawa Barat, dan Jawa Timur. Sedangkan dua wilayah yang produktivitas lahannya terendah adalah Provinsi Maluku digabung Maluku Utara dan Kalimantan Tengah. Jumlah tenaga kerja yang besar dan disertai besarnya produktivitas lahan dibanding wilayah lainnya menunjukkan alokasi penggunaan tenaga kerja di daerah tersebut telah dioptimalkan untuk menghasilkan produktivitas yang tinggi pula seperti misalnya Provinsi Jawa Timur berjumlah tenaga kerja tanaman pangannya 3,5 juta orang mampu menghasilkan produktivitas lahannya sebesar 22,89 juta rupiah per hektar- nya. Sedangkan bila wilayah yang jumlah tenaga kerjanya besar namun tidak dapat menghasilkan produktivitas lahannya yang tinggi seperti misalnya Provinsi Papua yang digabung dengan Papua Barat dengan jumlah tenaga kerja pertanian subsektor tanaman pangan 664 ribu orang dapat menghasilkan produktivitas lahannya sebesar 3,17 juta rupiah. Berbeda dengan wilayah Sumatera Barat yang berjumlah tenaga kerja sekitar 452 ribu orang dapat menghasilkan produktivitas lahannya lebih tinggi dibandingkan Provinsi Papua yakni sebesar 9,24 juta rupiah per hektar. Hal ini berarti alokasi sumberdaya manusia di Provinsi Papua tidak dimaksimalkan untuk menghasilkan produktivitas lahan tanaman pangan.

Perkembangan produktivitas lahan pada tahun 2006 terjadi peningkatan pertumbuhan produktivitas rata-rata dari 25 provinsi dengan laju sebesar 8,67 persen, sementara pertumbuhan intensitas penggunaan tenaga kerja rata-rata dari 25 provinsi meningkat dengan laju sebesar 2,43 persen. Produktivitas lahan terbesar di Provinsi Jawa Timur sebesar 23,39 juta rupiah per hektar, sedangkan terendah di Provinsi Maluku digabung Maluku Utara sebesar 1,75 juta rupiah per hektar.

Pada tahun 2007 pertumbuhan produktivitas rata-rata dari 25 provinsi bernilai positif namun lebih kecil dari tahun sebelumnya dengan laju sebesar 1,93 persen. Produktivitas lahan terbesar di Provinsi Jawa Timur sebesar 23,65 juta rupiah per hektar, sedangkan terendah di Provinsi Maluku digabung Maluku Utara. Pertumbuhan intensitas penggunaan tenaga kerja petani tanaman pangan rata-rata dari 25 provinsi ada penurunan laju dari tahun sebelumnya sebesar 3,24 persen.

Gambar 1 menunjukkan produktivitas lahan terbesar pada tahun 2008 berada di Provinsi Jawa Tengah digabung DIY sebesar 24,62 juta rupiah per hektar, sedangkan yang terendah di Provinsi Maluku digabung Maluku Utara sebesar 1,74 juta rupiah per hektar. Pertumbuhan produktivitas rata-rata dari 25 provinsi ada peningkatan daripada tahun sebelumnya dengan laju sebesar 2,92 persen, sementara pertumbuhan intensitas penggunaan tenaga kerja petani tanaman pangan rata-rata dari 25 provinsi terjadi peningkatan dengan laju 


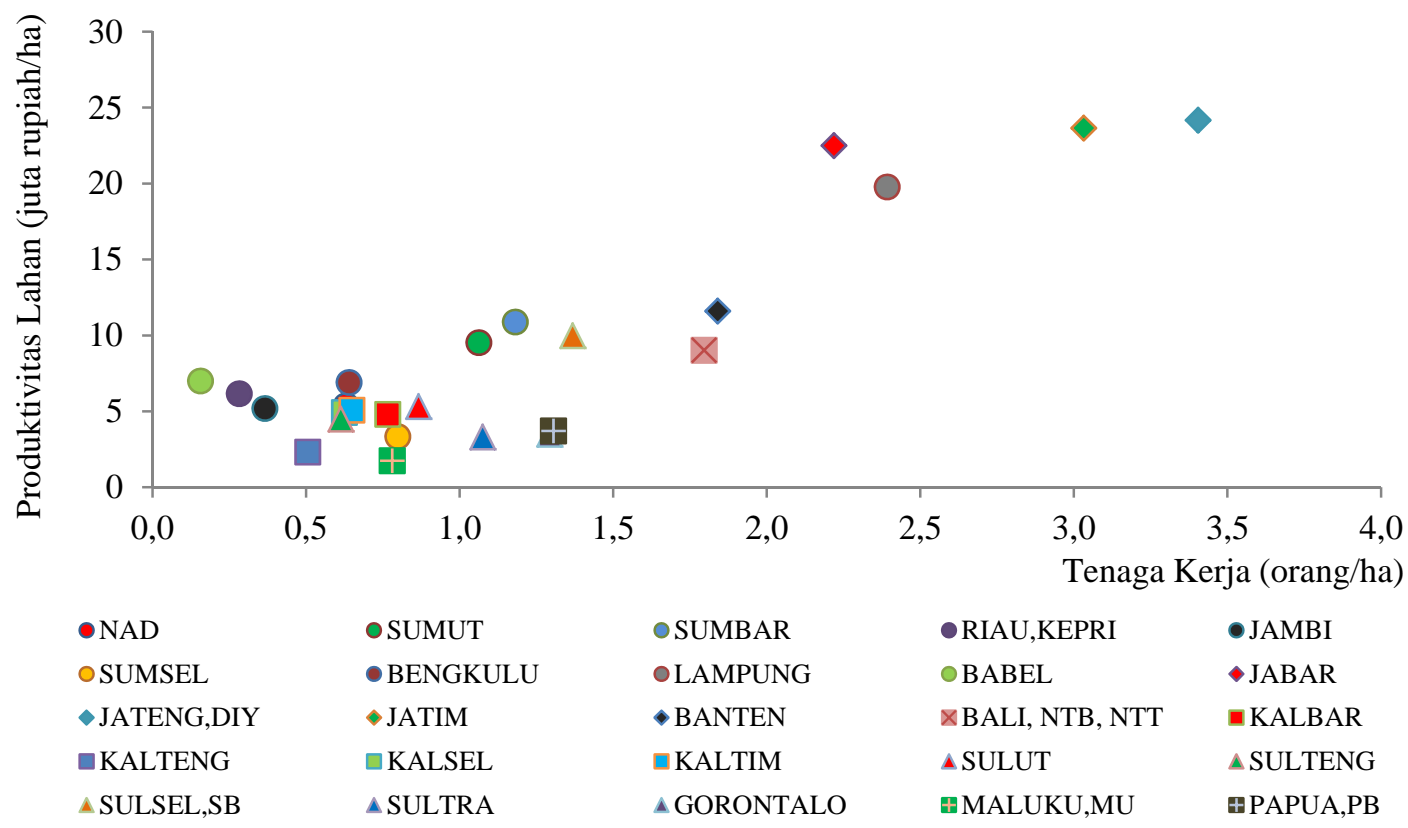

Sumber : BPS-Kementerian Pertanian (2011), diolah

Gambar 1. Hubungan Produktivitas Lahan Rata-rata dan Intensitas Penggunaan Tenaga Kerja Rata-rata

sebesar 28,94 persen.

Perkembangan nilai produktivitas lahan rata-rata dari 25 provinsi pada tahun 2009 terjadi peningkatan walaupun sangat kecil sebesar 8,88 juta rupiah per hektar. Namun pertumbuhan produktivitas lahan rata-rata dari 25 provinsi terjadi penurunan dengan laju sebesar 1,44 persen. Sementara pertumbuhan intensitas penggunaan tenaga kerja petani tanaman pangan rata-rata dari 25 provinsi juga menurun dengan laju sebesar 6,01 persen. Produktivitas lahan terbesar masih di Jawa Tengah digabung DIY sebesar 26,39 juta rupiah per hektar, sedangkan terendah masih di Maluku digabung Maluku Utara sebesar 1,74 juta rupiah per hektar. Secara keseluruhan pertumbuhan produktivitas lahan pertanian tanaman pangan meningkat dengan laju ratarata pertumbuhan dari 25 provinsi sebesar 2,52 persen. Sedangkan rata-rata pertumbuhan intensitas penggunaan tenaga kerja pertanian tanaman pangan dari 25 provinsi menurun dengan laju sebesar 0,17 persen.

Gambar 2 menggambarkan sebaran nilai hubungan produktivitas lahan rata-rata dan intensitas penggunaan modal rata-rata pertanian tanaman pangan di 25 provinsi selama 2005-2009. Bila dianalisis lebih dalam laju ratarata pertumbuhan intensitas penggunaan modal pertanian tertinggi selama periode 20052009 adalah Provinsi Kalimantan Timur sebesar 51,54 persen dan juga memiliki laju rata-rata pertumbuhan produktivitas lahan tertinggi sebesar 13,27 persen, namun produktivitas lahan pertanian tanaman pangan hanya sekitar 5 juta rupiah/hektar tidak sebesar seperti Provinsi Jawa Timur. Hal ini diduga karena alokasi penggunaan modal pertanian di wilayah tersebut tidak sebagian besar untuk penggunaan komoditas tanaman pangan, Provinsi Kalimantan Timur memiliki potensi hutan lebih besar daripada potensi tanaman pangannya. Hal yang sama diduga terjadi pula di wilayah Provinsi Sumatera Utara, Kalimantan Tengah, Jambi yang memiliki potensi perkebunan lebih besar daripada tanaman pangan sehingga menyebabkan alokasi penggunaan modal tidak digunakan sebagian besar untuk komoditas tanaman pangan.

Perkembangan intensitas penggunaan modal pertanian tanaman pangan pada tahun 2005 terbesar di Provinsi Jawa Timur sebesar 4,06 juta rupiah per hektar, sedangkan terendah di Provinsi NAD sebesar 0,15 juta rupiah per hektar. Sedangkan perkembangan pada tahun 2006 pertumbuhan intensitas penggunaan modal pertanian tanaman pangan rata-rata dari 25 provinsi dengan lajunya sebesar 24,05 per- 


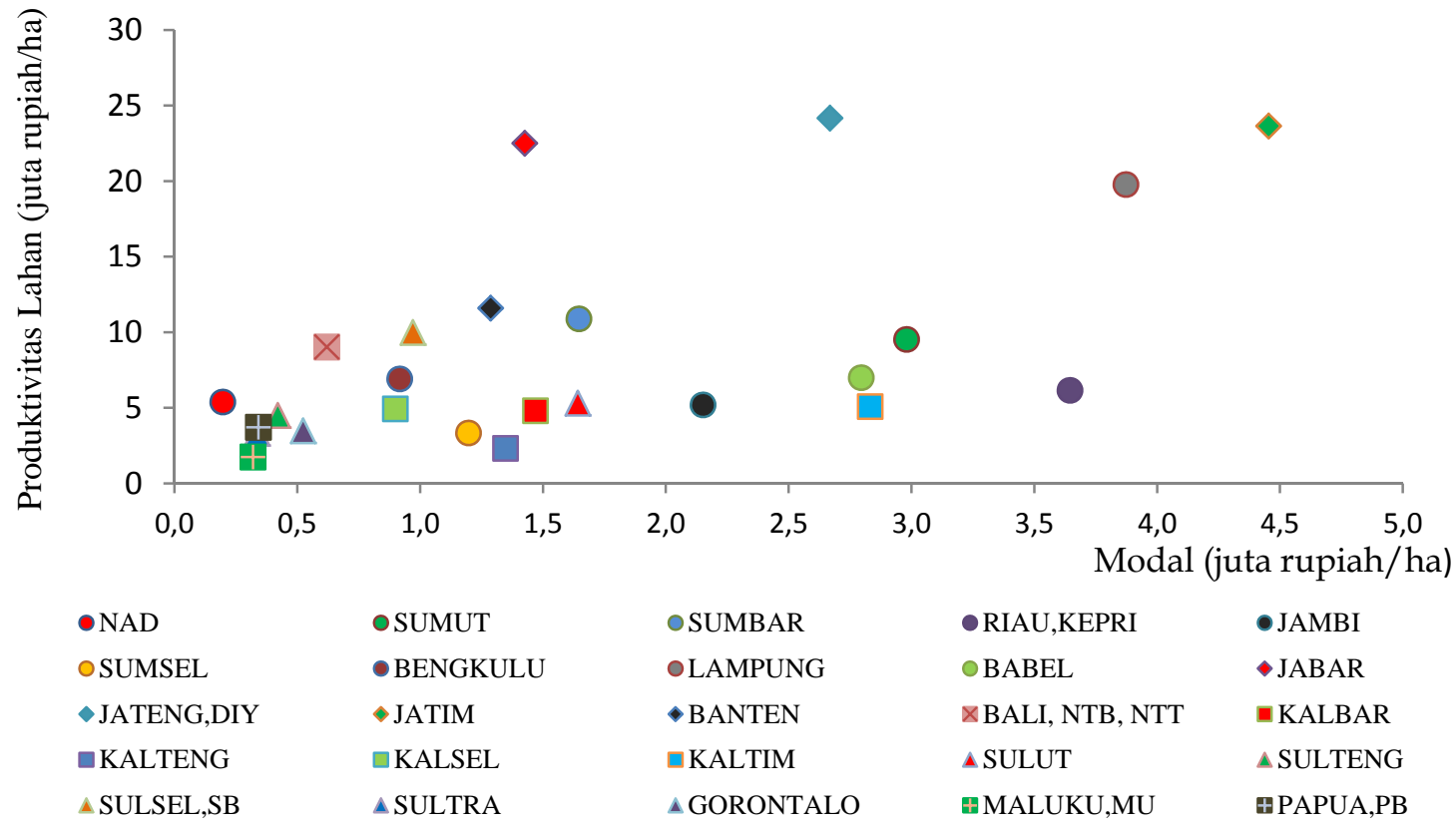

Sumber : BPS-Kementerian Pertanian (2011), diolah

Gambar 2. Hubungan Produktivitas Lahan Rata-rata dan Intensitas Penggunaan Modal Rata-rata

sen. Intensitas penggunaan modal pertanian tanaman pangan terbesar di Provinsi Jawa Timur sebesar 3,42 juta rupiah per hektar, sedangkan terendah di Provinsi NAD sebesar 0,15 juta rupiah per hektar.

Pertumbuhan intensitas penggunaan modal terjadi penurunan dibandingkan tahun sebelumnya pada tahun 2007 dengan laju pertumbuhan rata-ratanya dari 25 provinsi sebesar 21,67 persen. Intensitas penggunaan modal terbesar di Provinsi Jawa Timur sebesar 4,13 juta rupiah per hektar, sedangkan terendah di Provinsi NAD sebesar 0,2 juta rupiah per hektar. Sementara tahun 2008 juga terjadi peningkatan intensitas penggunaan modal pertanian tanaman pangan dengan laju pertumbuhan rata-ratanya dari 25 provinsi sebesar 32,48 persen. Intensitas penggunaan modal pertanian tanaman pangan terbesar di Provinsi Jawa Timur sebesar 5,35 juta rupiah per hektar, sedangkan terendah di Provinsi NAD sebesar 0,26 juta rupiah per hektar.

Perkembangan pertumbuhan intensitas penggunaan modal di tahun 2009 lebih kecil dibandingkan tahun sebelumnya dengan laju rata-ratanya dari 25 provinsi menjadi 10,22 persen. Intensitas penggunaan modal pertanian tanaman pangan terbesar di Provinsi Lampung sebesar 6,67 juta rupiah per hektar, sedangkan terendah di Provinsi NAD sebesar 0,27 juta rupiah per hektar. Secara keseluruhan pertumbuhan tahunan rata-rata dari 25 provinsi atas intensitas penggunaan modal tumbuh positif dengan laju sebesar 17,28 persen.

Gambar 3 menunjukkan hubungan antara rata-rata produktivitas lahan pertanian dengan intensitas penggunaan anggaran riset pertanian rata-rata selama tahun 2005-2009. Perkembangan intensitas penggunaan anggaran riset pertanian pada tahun 2005 terbesar di Provinsi Bangka Belitung sebesar 47,26 ribu rupiah/ha, sedangkan terendah di Provinsi NAD sebesar 3,89 ribu rupiah/ha.

Peningkatan pertumbuhan intensitas penggunaan anggaran riset pertanian terjadi pada tahun 2006 dengan laju rata-rata dari 25 provinsi sebesar 66,81 persen. Intensitas penggunaan anggaran riset pertanian terbesar di Provinsi Bangka Belitung sebesar 78,99 ribu rupiah/ha, sedangkan terkecil di Provinsi Sumatera Selatan sebesar 8,63 ribu rupiah/ha. 


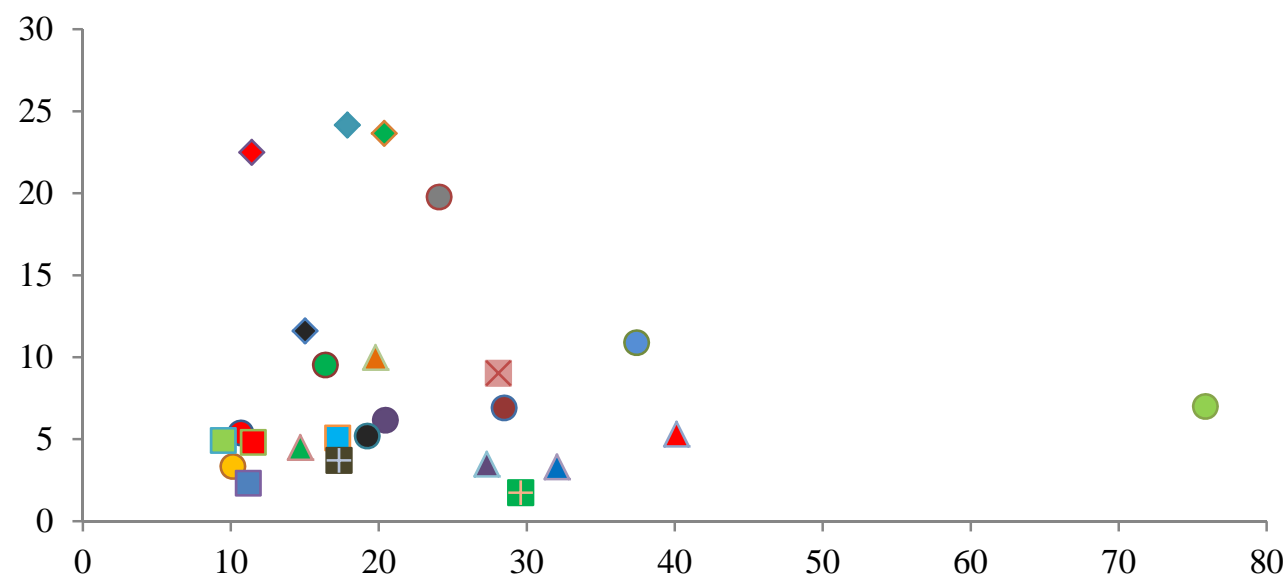

Riset (000 rupiah/ha)

\begin{tabular}{|c|c|c|c|c|}
\hline - NAD & - SUMUT & - SUMBAR & - RIAU,KEPRI & - JAMBI \\
\hline OSUMSEL & - BENGKULU & - LAMPUNG & ○ BABEL & $\bullet$ JABAR \\
\hline$\bullet$ JATENG,DIY & $\bullet$ JATIM & - BANTEN & × BALI, NTB, NTT & = KALBAR \\
\hline$\square$ KALTENG & $\square$ KALSEL & ॠALTIM & $\triangle$ SULUT & $\triangle$ SULTENG \\
\hline$\triangle$ SULSEL,SB & $\triangle$ SULTRA & $\triangle$ GORONTALO & \#MALUKU,MU & \#PAPUA,PB \\
\hline
\end{tabular}

Sumber : BPS-Kementerian Pertanian (2011), diolah

Gambar 3. Hubungan Produktivitas Lahan Rata-Rata dan Intensitas Penggunaan Anggaran Riset Pertanian Rata-Rata

Perkembangan pertumbuhan intensitas penggunaan anggaran riset pertanian pada tahun 2007 laju rata-rata dari 25 provinsi sebesar 62,58 persen. Intensitas penggunaan anggaran riset pertanian terbesar di Provinsi Bangka Belitung sebesar 96,44 ribu rupiah/ha, sedangkan yang terkecil di Provinsi Kalimantan Selatan sebesar 11,25 ribu rupiah/ha. Laju pertumbuhan rata-rata intensitas penggunaan anggaran riset pertanian dari 25 provinsi pada tahun 2008 mengalami penurunan sebesar 5,98 persen. Intensitas penggunaan anggaran riset pertanian terbesar yakni di Provinsi Bangka Belitung sebesar 76,63 ribu rupiah/ha, sedangkan yang terendah di Provinsi Kalimantan Selatan sebesar 9,74 ribu rupiah/ha. Intensitas penggunaan anggaran riset pertanian pada tahun 2009 laju pertumbuhan rata-rata dari 25 provinsi meningkat lagi dengan laju sebesar 11,93 persen. Secara keseluruhan pertumbuhan anggaran penelitian cenderung meningkat selama periode 2005-2009 dengan laju sebesar 26,88 persen.

Gambar 4 menggambarkan hubungan produktivitas lahan rata-rata dengan intensitas penggunaan lahan teririgasi rata-rata selama periode 2005-2009. Semakin besar intensitas penggunaan lahan teririgasi, maka semakin besar kemungkinan tanaman pangan memperoleh kebutuhan kecukupan air. Dampaknya akan meningkatkan hasil produksi tanaman pangan sehingga meningkatkan produktivitas komoditas tanaman pangan terutama komoditas padi yang membutuhkan air relatif lebih banyak dibandingkan komoditas tanaman pangan lainnya.

Pada tahun 2005 intensitas penggunaan lahan teririgasi terbesar di Provinsi Jawa Timur sebesar 0,77. Sedangkan terkecil di Provinsi Papua digabung Papua Barat sebesar 0,04. Perkembangan intensitas penggunaan lahan teririgasi pada tahun 2009, Provinsi Jawa Timur masih terbesar dengan intensitas penggunaan lahan teririgasi sebesar 0,77 sedangkan yang terendah adalah Provinsi Riau sebesar 0,04. Sementara Provinsi Papua intensitas penggunaan lahan teririgasi meningkat menjadi 0,06.

Gambar 5 menunjukkan gambaran hubungan antara produktivitas lahan rata-rata dengan intensitas kualitas sumber daya manusia rata- 


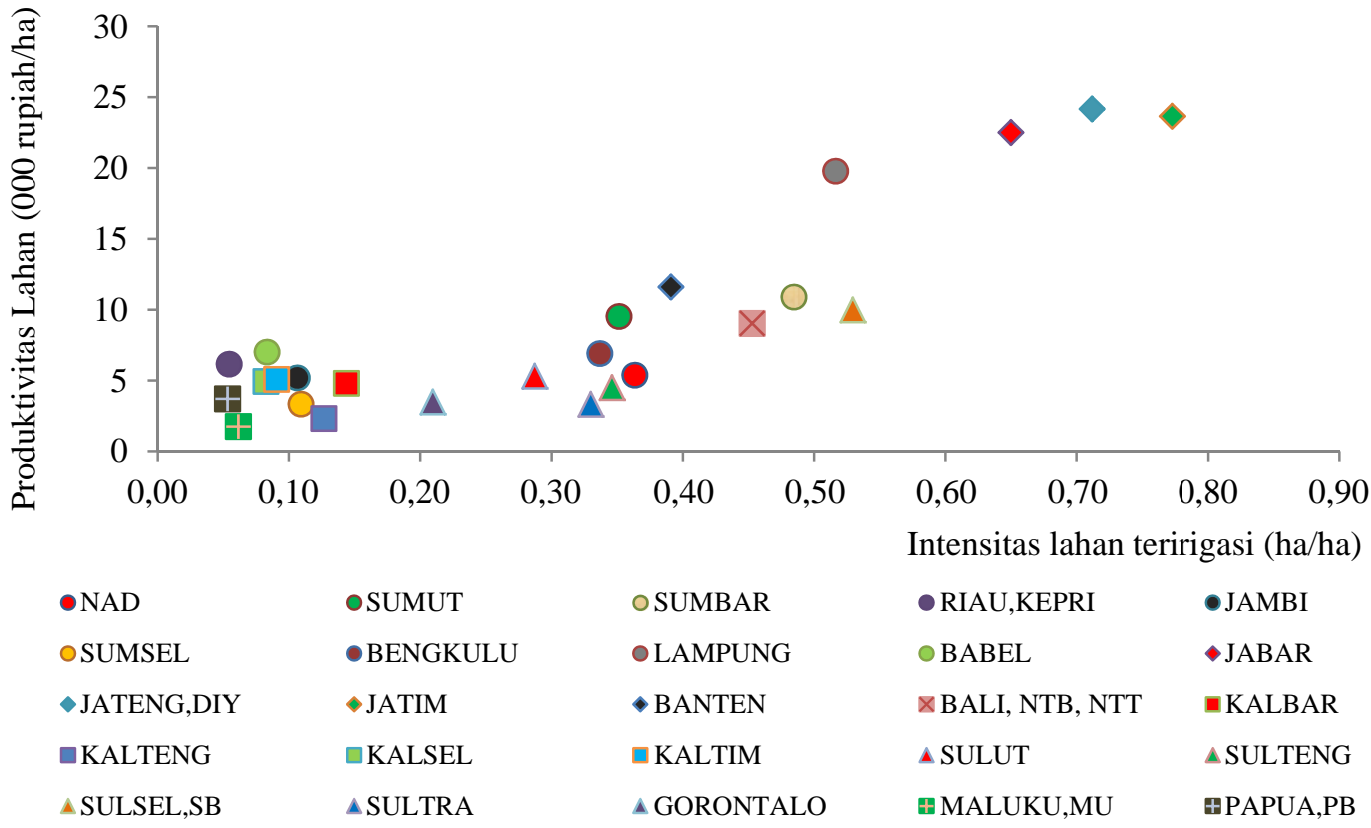

Sumber : BPS-Kementerian Pertanian (2011), diolah

Gambar 4. Hubungan Produktivitas Lahan Rata-rata dan Intensitas Lahan Teririgasi Rata-rata

rata dengan pendekatan rata-rata lama sekolah di 25 provinsi selama tahun 2005-2009. Pada tahun 2005 rata-rata lama sekolah petani tanaman pangan terbesar di Provinsi Sulawesi Utara sebesar 7,21 tahun, sedangkan terendah di Provinsi Papua digabung Papua Barat sebesar 4 tahun. Perkembangan rata-rata lama sekolah petani tan aman pangan pada tahun 2009 wilayah yang rata-rata lama sekolah terbesar masih di Provinsi Lampung, sedangkan terendah masih di Provinsi Papua digabung Papua Barat. Secara keseluruhan nilai

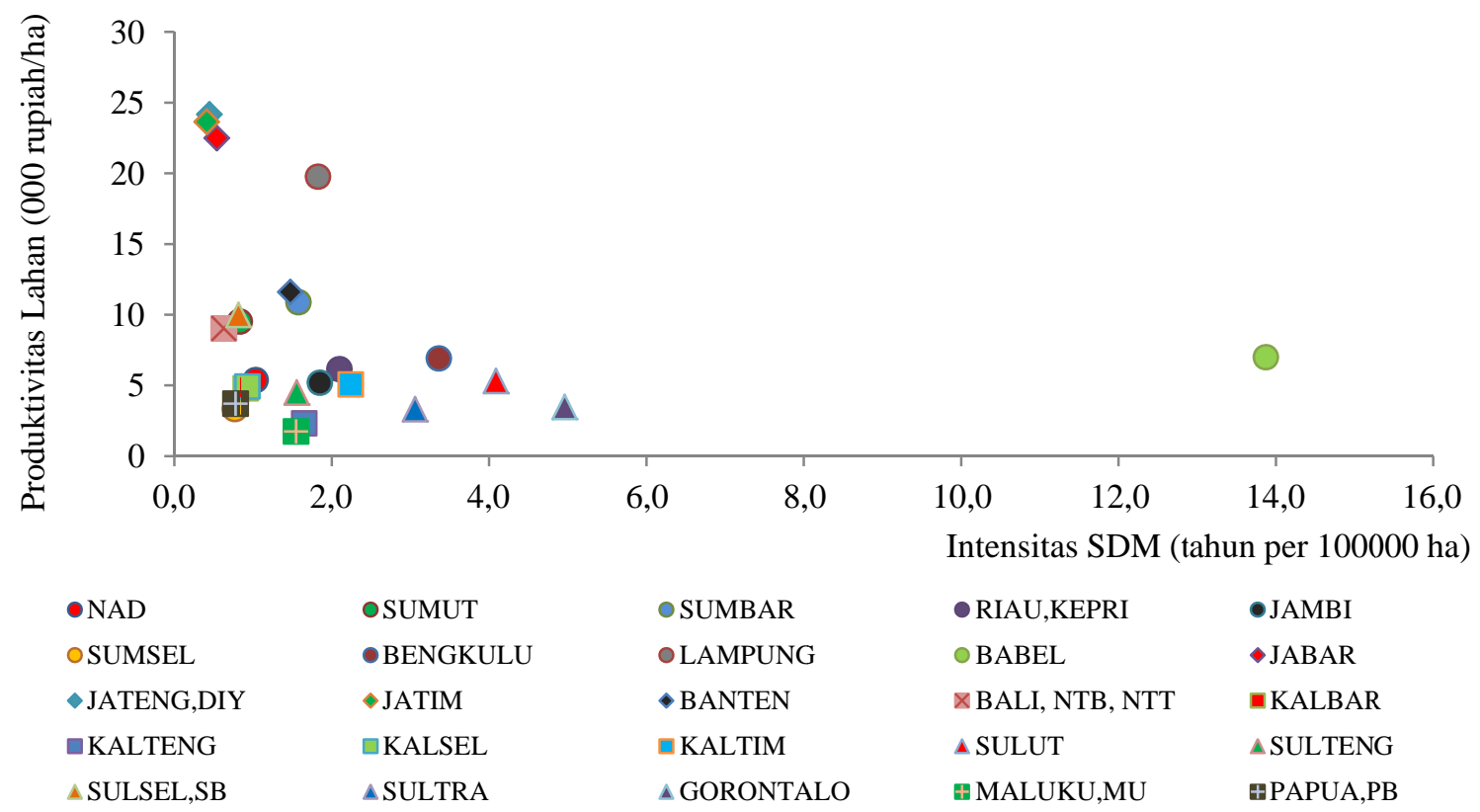

Sumber : BPS-Kementerian Pertanian (2011), diolah

Gambar 5. Hubungan Produktivitas Lahan Rata-rata dan Intensitas Kualitas Sumber Daya Manusia Ratarata 


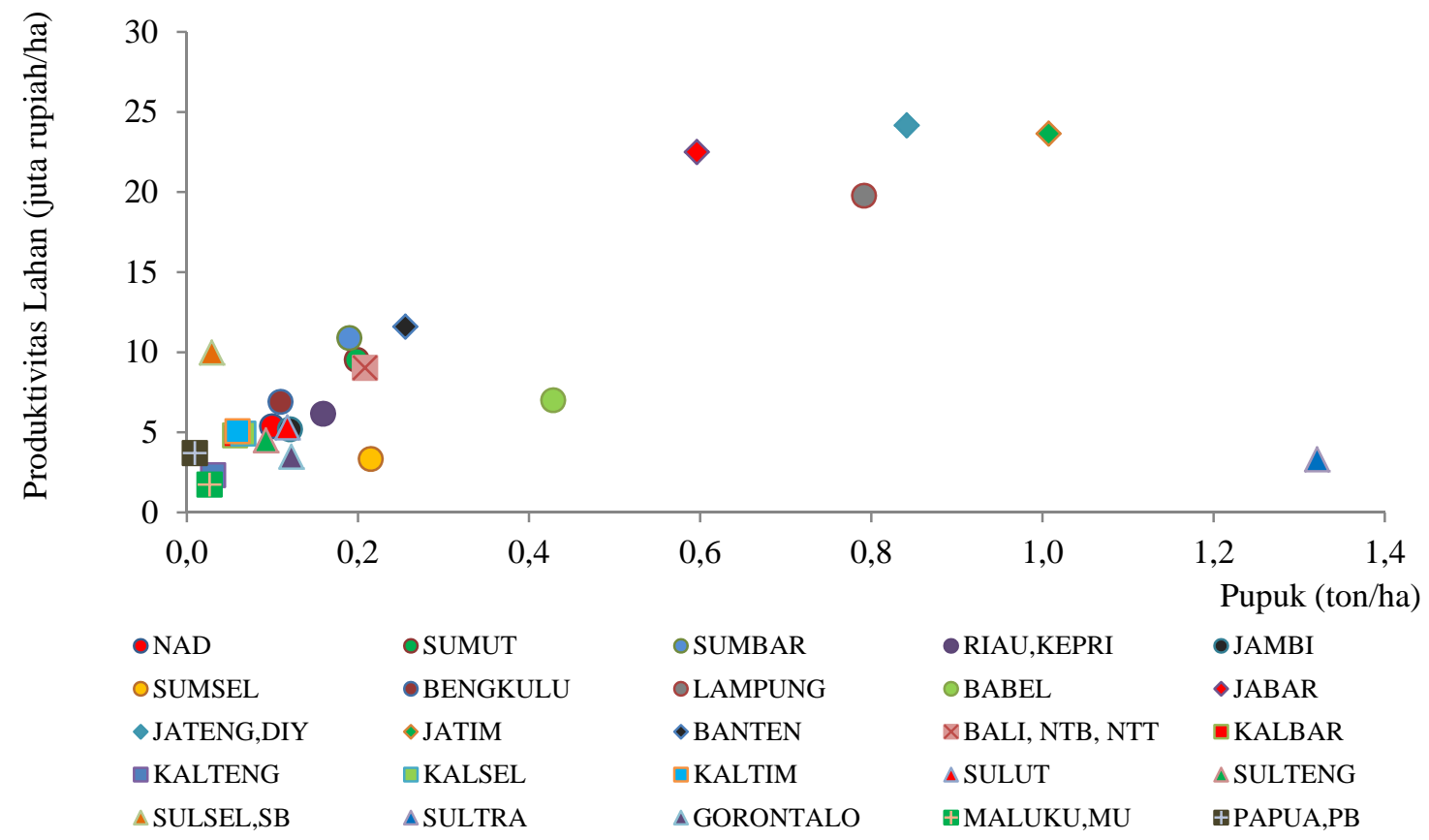

Sumber: BPS-Kementerian Pertanian (2011), diolah

Gambar 6. Hubungan Produktivitas Lahan Rata-rata dan Intensitas Penggunaan Pupuk Urea Rata-rata.

rata-rata pertumbuhan rata-rata lama sekolah petani tanaman pangan dari 25 provinsi lajunya sebesar 0,69 persen.

Faktor sumber daya manusia dengan pendekatan rata-rata lama sekolah ini dapat menjadi modal dasar petani untuk menerima transfer pengetahuan tentang teknologi atau dalam rangka mengadaptasi hasil riset pertanian terbaru. Karena keberhasilan upaya penyuluhan dari pemerintah juga perlu didukung oleh tingkat pendidikan agar paling tidak dalam mengaplikasikan obat pestisida pertanian yang baru, pupuk organik sesuai dosisnya. Tingkat pendidikan ini juga mempermudah petani untuk mencari informasi tentang hasil inovasi terbaru benih unggul melalui internet yang sekarang dapat diakses di pedesaan tempat tinggal petani.

Gambar 6 menggambarkan hubungan antara produktivitas lahan rata-rata dengan penggunaan pupuk per unit satuan lahan yang digunakan tanaman pangan di 25 provinsi selama periode 2005-2009. Pupuk kimia seperti salah satunya urea merupakan salah satu alat input kebutuhan petani untuk meningkatkan hasil usaha pertanian tanaman pangan. Namun bila dosis p enggunaan pupuk urea tidak sesuai dosis maka akan menyebabkan kerusakan struktur kualitas tanah sehingga hasil produksi tanaman pangan tidak optimal.

Pada tahun 2005 intensitas penggunaan pupuk urea terbesar di Provinsi Sulawesi Tenggara sebesar 1,416 ton/hektar/tahun, bila di daerah tersebut diusahakan 3 kali dalam setahun dosis penggunaan pupuknya masih terlalu besar, tidak sesuai dengan anjuran Kementerian Pertanian sebesar 200-300 kg/ hektar (Balitbang-Kementerian Pertanian, 2008). Sedangkan wilayah yang intensitas penggunaan pupuk terendah di Provinsi Sulawesi Selatan sebesar 0,023 ton/hektar/tahun, dosis yang masih di bawah anjuran dari Kementerian Pertanian. Berbeda dengan wilayah Provinsi Jawa Tengah digabung DIY yang menggunakan pupuk urea sebesar 0,789 ton/hektar/ tahun, bila diusahakan 3 kali dalam setahun dosisnya masih sesuai aturan sehingga menghasilkan produktivitas lahan yang optimal.

\section{Analisis Hasil Regresi}

Model fixed effect yang menggunakan estimasi Generalized Least Square (GLS) dengan pembobotan terhadap crosssection dapat dilihat pada Tabel 1. Terdapat dua variabel yang tidak berpengaruh terhadap produktivitas lahan pertanian 
Tabel 1. Hasil Estimasi Model

\begin{tabular}{lc}
\hline \multicolumn{1}{c}{ Variabel } & Nilai \\
\hline Konstanta & $9,453632^{* * *}$ \\
Tenaga Kerja/Lahan & $(0,831563)$ \\
Modal/ Lahan & $-0,009583$ \\
& $(0,028035)$ \\
Riset / Lahan (lag tahun ke 2) & $0,033765^{* * *}$ \\
& $(0,010299)$ \\
Lahan Teririgasi X Dummy Infrastruktur Irigasi & $0,041810^{* * *}$ \\
Sumber daya manusia / Lahan & $(0,008129)$ \\
Pupuk / Lahan & $0,175725^{* *}$ \\
R2 & $(0,071815)$ \\
Adjusted R & $0,675189^{* * *}$ \\
F-Statistik & $(0,074569)$ \\
\end{tabular}

Sumber : Hasil pengolahan data penelitian
Ket : ** Signifikan pada taraf nyata $5 \%,{ }^{* * *}$ Signifikan pada taraf nyata $1 \%$,
Angka dalam kurung merupakan standard error

tanaman pangan. Variabel tersebut adalah pupuk dan variabel tenaga kerja.

Selanjutnya dari hasil estimasi pada Tabel 1 dapat diinterpretasikan bahwa modal mempengaruhi produktivitas lahan dengan bertanda positif sesuai dengan hipotesis alternatif pada hipotesis uji dengan nilai elastisitas sebesar 0,03. Artinya peningkatan 1 persen modal yang diberikan untuk usaha pertanian akan meningkatkan 0,03 persen produktivitas lahan pertanian subsektor tanaman pangan, dengan asumsi bahwa variabel-variabel lain adalah tetap. Hal ini menjelaskan bahwa usaha pertanian komoditas tanaman pangan membutuhkan kredit sebagai salah satu sumber modal usahanya. Walaupun banyak dipertentangkan bahwa kredit bukan sumber utama permodalan usaha pertanian. Modal yang bersumber dari kredit akan menolong petani yang kesulitan mendapatkan modal.

Modal yang diperoleh tersebut dapat digunakan untuk pembelian input produksi seperti bibit/benih tanaman pangan, pestisida, dan sarana produksi lainnya seperti mesin traktor, dan alat yang mahal lainnya. Selain itu dengan fasilitas kredit seseorang dapat meningkatkan konsumsi sehingga nutrisi seseorang akan meningkat yang berakibat meningkatnya produktivitas tenaga kerja dan akan meningkatkan produktivitas lahan Carter (1989).

Riset berpengaruh positif terhadap produktivitas lahan sehingga sesuai dengan hipotesis alternatif pada hipotesis uji. Anggaran riset dan pengembangan pertanian merupakan bentuk inovasi input produksi baik berupa bibit unggul maupun teknologi praktis yang dapat meningkatkan produktivitas lahan. Peningkatan anggaran riset dan pengembangan seyogyanya disertai peningkatan kinerja para ahli di bidang pertanian untuk menghasilkan penemuan-penemuan baru dan uji coba praktek di lapangan atas hasil penemuan tersebut. Semakin banyak uji coba praktik di lapangan dengan hasil yang mampu meningkatkan produksi akan menyebabkan petani pun tertarik untuk menggunakan teknologi tersebut. Karena petani Indonesia cenderung tidak berani menggunakan bibit baru sebelum terbukti hasilnya dapat meningkatkan produksi usaha tanaman pangan tersebut. Riset pada penelitian ini berpengaruh terhadap produktivitas lahan dengan nilai elastisitas sebesar 0,04 artinya peningkatan penelitian dan pengembangan pertanian sebesar 1 persen akan meningkatkan produktivitas lahan pertanian tanaman pangan sebesar 0,04 persen, dengan asumsi bahwa variabel-variabel 
lain adalah tetap. Riset berpengaruh positif terhadap produktivitas lahan pertanian subsektor tanaman pangan setelah dua tahun kemudian.

Sementara itu sumber daya manusia berpengaruh terhadap produktivitas lahan, sesuai dengan hipotesis alternatif pada hipotesis uji. Nilai elastisitasnya sebesar 0,67 artinya setiap terjadi peningkatan 1 persen pada sumber daya manusia yang diukur oleh rata-rata lama sekolah pekerja pertanian tanaman pangan per unit lahan pertanian tanaman pangan akan meningkatkan produktivitas lahan pertanian tanaman pangan sebesar 0,67 persen, dengan asumsi bahwa variabel-variabel lain adalah tetap. Hal ini menggambarkan bahwa semakin tinggi jenjang pendidikan formal, petani akan berupaya untuk meningkatkan produktivitas lahan pertanian tanaman pangan dengan mengadopsi teknologi baru dalam bertani. Selain teknologi yang bersumber dari penyuluhan langsung di lapangan, petani dapat berupaya mencari informasi melalui penyebaran informasi melalui media cetak dari Kementerian Pertanian atau media internet.

Lahan yang teraliri irigasi berpengaruh positif terhadap produktivitas lahan tanaman pangan dengan nilai elastisitas sebesar 0,17 artinya setiap peningkatan perluasan irigasi yang berlokasi di Pulau Jawa dan Sumatera sebesar 1 persen akan berpengaruh terhadap peningkatan produktivitas lahan pertanian tanaman pangan sebesar 0,17 persen, dengan asumsi bahwa variabel-variabel lain adalah tetap. Ketersediaan air merupakan faktor utama dalam usaha tani komoditas tanaman pangan. Karena kecukupan air untuk memenuhi kebutuhan tanaman pangan ini untuk mengantisipasi terjadinya musim kemarau. Pemeliharaan jaringan irigasi dan perbaikan manajemen distribusi air irigasi sangat diperlukan sebagai penyedia air. Kebutuhan irigasi untuk masingmasing komoditas tanaman pangan berbedabeda. Karena komoditas padi di Indonesia merupakan komoditas dominan diantara lainnya maka perluasan irigasi diarahkan kepada lahan yang masih diusahakan oleh petani untuk menanam padi.

Pupuk tidak berpengaruh terhadap produktivitas lahan pertanian subsektor tanaman pangan, sehingga sesuai dengan hipotesis null pada hipotesis uji. Hal ini diduga pupuk urea bukan merupakan input yang efektif. Hasil yang serupa dengan penelitian yang dilakukan oleh Pingali and Rosegrant (1994) yang menyebutkan bahwa penyebab kelelahan lahan pertanian karena terbentuknya tanah keras dan padat, serta berkurangnya kemampuan tanah dalam penyediaan unsur nitrogen.

Sedangkan tenaga kerja tidak berpengaruh terhadap produktivitas lahan pertanian subsektor tanaman pangan. Hal ini sesuai dengan hipotesis null pada hipotesis uji. Diduga tidak berpengaruhnya jumlah tenaga kerja terhadap produktivitas lahan pertanian subsektor tanaman pangan, karena tenaga kerja pertanian sudah banyak dan mengalami surplus tenaga kerja. Artinya penambahan jumlah tenaga kerja pertanian tanaman pangan tidak mempengaruhi output karena lahan garapan petani juga semakin berkurang. Sedangkan program intensifikasi pertanian terus digalakkan.

Efek individu dari hasil estimasi model terbaik diperoleh bahwa variabel lain di luar persamaan model 3 yang dapat memengaruhi produktivitas lahan pertanian subsektor tanaman pangan adalah wilayah Provinsi Jawa Tengah tergabung DIY dan Provinsi Jawa Timur dengan koefisien masing-masing sebesar 11,45 poin dan 11,44 poin. Artinya terdapat variabel lain di wilayah provinsi tersebut yang dapat memengaruhi produktivitas lahan pertanian subsektor tanaman pangan. Variabelvariabel yang diduga tersebut diasumsikan adalah besaran tenaga kerja penyuluh pertanian dan kualitas tanah di Pulau Jawa lebih banyak daripada di luar Pulau Jawa. Hasil penelitian yang pernah dilakukan oleh Kusmiyati, Maryani dan Kusnadi (2010) menyebutkan pentingnya peran penyuluh untuk memotivasi petani dalam upaya peningkatan produktivitas pertanian. Selain itu faktor internal yang dapat memengaruhi kinerja penyuluh adalah tingkat pendidikan formal. Bila dilihat dari distribusi jumlah tenaga kerja penyuluh pertanian seIndonesia, jumlah penyuluh di Jawa Timur sebanyak 2775 orang dengan komposisi tingkat pendidikan diploma III/IV sebanyak 456 orang, Strata 1 sebanyak 1.830 orang, dan Strata 2 sebanyak 62 orang, sisanya lulusan SLTA. Sedangkan di Provinsi Jawa Tengah sejumlah 
2.568 orang penyuluh dan di Provinsi DIY sejumlah 318 orang (Rekapitulasi Penyuluh Pertanian, 2012). Hasil penelitian Badan penelitian tanah Kementerian Pertanian (2011) menyebutkan terkonsentrasinya lahan persawahan di Pulau Jawa berkaitan dengan jenis tanah yang berasal dari bahan induk endapan vulkanik, yang secara alami lebih subur daripada tanah-tanah di luar Pulau Jawa.

\section{SIMPULAN}

Berdasarkan hasil penelitian yang telah diperoleh, akhirnya dapat ditarik beberapa kesimpulan bahwa produktivitas lahan tiga wilayah terbesar berada di Provinsi Jawa Tengah termasuk DIY, Jawa Timur, Jawa Barat dengan nilai masing-masing sebesar 24,10 juta rupiah/ha, 23,60 juta rupiah/ha, dan 22,50 juta rupiah/ha. Produktivitas lahan terendah berada di Provinsi Maluku termasuk Maluku Utara sebesar 1,70 juta rupiah/ha. Perkembangan produktivitas lahan dari tahun 2005-2009 cenderung meningkat dengan laju pertumbuhan per tahun yang positif sebesar 2,38 persen.

Beberapa faktor yang dapat berpengaruh positif terhadap produktivitas lahan pertanian subsektor tanaman pangan yakni anggaran penelitian dan pengembangan pertanian, modal, lahan pertanian yang teraliri irigasi, dan sumber daya manusia dengan pendekatan ratarata lama sekolah yang dimiliki pekerja pertanian. Sedangkan faktor yang tidak berpengaruh terhadap produktivitas lahan pertanian subsektor tanaman pangan adalah pupuk dan tenaga kerja.

Saran. Penelitian selanjutnya dapat mengkaji lebih dalam tentang kualitas sumber daya manusia berupa tingkat pengalaman pekerja tanaman pangan dalam berusaha tani tanaman pangan melalui data pelatihan-pelatihan yang telah diselenggarakan oleh pemerintah baik formal maupun informal.

Terdapat beberapa faktor lain yang belum terobservasi dalam penelitian ini seperti kualitas lahan, organisme pengganggu tanaman (OPT) dan curah hujan. Saran untuk penelitian selanjutnya, variabel-variabel tersebut dapat digunakan untuk mengkaji faktor-faktor lain yang dapat mempengaruhi produktivitas lahan pertanian subsektor tanaman pangan. Penggunaan variabel tersebut perlu dikaji dalam ruang lingkup provinsi/kabupaten agar diperoleh pendekatan data yang lebih baik.

Penggunaan variabel pupuk urea sebagai pendekatan variabel pupuk masih terbatas dalam penelitian ini. Saran penelitian selanjutnya dapat dimodifikasi dengan menambahkan faktor pupuk lainnya seperti pupuk organik. Penggunaan variabel tersebut perlu dikaji dalam satu periode musim tanam agar diperoleh pendekatan data yang lebih baik.

\section{DAFTAR PUSTAKA}

Alene, A.D., and O. Coulibaly. (2008). The Impact of Agricultural Research on Productivity and Poverty in sub-Saharan Africa. Journal Food Policy 34.p.198-209.

Badan penelitian dan pengembangan pertanian. 2005-2009 (tahunan). Statistik Penelitian Pertanian. Jakarta: Kementerian Pertanian.

Badan Penelitian dan Pengembangan Pertanian-Kementan. 2005. Prospek dan Arah Pengembangan Agribisnis: Tinjauan Aspek Kesesuaian Lahan. Jakarta: Balitbang-Kementerian Pertanian.

Badan Penelitian dan Pengembangan Pertanian-Kementerian Pertanian. (2006). Kumpulan Istilah Ilmu Tanah. Jakarta: Balitbang-Kementerian Pertanian.

Badan Penelitian Tanah-Kementerian Pertanian. Nopember 20, 2011. http://balittanah. litbang.deptan.go.id/eng/dokumentasi/b uku/tanahsawah/tanahsawah5.pdf

Badan Pusat Statistika. 2004). Sensus Pertanian. Jakarta: BPS.

Badan Pusat Statistika. 2005-2010 (tahunan). Statistik Indonesia. Jakarta: BPS.

Badan Pusat Statistika. 2011. Ensiklopedia Indikator Ekonomi dan Sosial. Jakarta: BPS.

Badan Pusat Statistika -Kementerian Pertanian. 2010. Data Sub Sistem Hulu (CD- ROM). Jakarta: Pusdatin-BPS. 
Balai Besar Pengkajian dan Pengembangan Teknologi Pertanian-BALITBANG Kementerian Pertanian (Kementan). (2008). Teknologi Budidaya Padi. Jakarta: Badan Penelitian dan Pengembangan PertanianKementerian Pertanian.

Balai Besar Pengkajian dan Pengembangan Teknologi Pertanian-BALITBANG Kementerian Pertanian (Kementan). 2008. Teknologi Budidaya Ubi Kayu. Jakarta: Badan Penelitian dan Pengembangan Pertanian-Kementerian Pertanian.

Baltagi, B.H. 2005. Econometric Analysis of Panel Data 3rd ed. England: John Wiley and Sons, Ltd.

Bank Indonesia. 2005-2010 (bulanan). Statistik Ekonomi dan Keuangan Daerah (SEKDA) provinsi-provinsi di Indonesia. Jakarta: Bank Indonesia.

Basis Data Statistik Pertanian. September 1, 2011. http://aplikasi.deptan.go.id/bdsp/ newkom.asp

Carter,M.R. 1989. The Impact of Credit on Peasant Productivity and Differentiation in Nicaragua. Journal of Development Economics 31, 13-36.

Daniel, Moehar. 2004. Pengantar Ekonomi Pertanian. Jakarta: Bumi Aksara.

Evenson, R.E. and C.E. Pray. 1991. Research and Productivity in Asian Agriculture. Ithaca: Cornell University Press.

Gaiha, Raghav and K. Imai. 2008. Agricultural Growth, Employment, and Wage Rates in Developing Countries in Berlin Workshop Series. World Bank.

Griffith, William E.,Hill, R.C. and Lim, G.C. 2008. Using Eviews for Principle of Econometrics. Australia: John Wiley and Sons, Inc.

Hardjowigeno, S. 1987. Ilmu tanah. Medyatama Sarana Perkasa.

Haider M.Z. 2011. Technical Efficiency of Agricultural Farms in Khulna, Bangladesh: Stochastic Frontier Approach. International Journal of Economic and Science Vol.3 No.3.
Iqbal, M. M. Ahmad, and K. Abbas. 2003. The Impact of Institutional Credit on Agricultural Production in Pakistan. MPRA. No. 3673.

Irawan, B.., B. Winarso, I. Sadikin, dan G.S. Hardono. 2003. Analisis Faktor Penyebab Pelambatan Produksi Komoditas Tanaman Utama. Bogor: Pusat Penelitian dan Pengembangan Sosial Ekonomi Pertanian.

Kiani, Adiqa K. 2008. Farm Size and Productivity in Pakistan. European Journal of Science Vol.7 No.2.

Kusmiyati, Maryani Ait dan Kusnadi, Dedi. 2010. Kinerja Penyuluh Pertanian PNS dalam Melaksanakan Tupoksi Di Kabupaten Bogor (Kasus di BP3K Cibungbulang). Bogor: Jurnal Penyuluhan Pertanian Vol. 5 No.1. Mei.

Li, J., Y. Xin, and L. Yuan. 2009. Hybrid Rice Technology Development Ensuring China's Food Security. IFPRI Discussion Paper 00918-CGIAR.

Luh, Yir-Hueih, C.C. Chang, and Fung-Mey Huang. 2008. Efficiency Change and Productivity Growth in Agriculture: A Comparative Analysis for Selected East Asian Economics. Journal of Asian Economics. Vol.19 p.312-324

Masterson, T. 2007. Productivity, Technical Efficiency, and Farm Size in Paraguayan Agriculture. WP. No. 490. The Levy Economic Institute of Bard College.

Olayide, S. Olajuwon and E.O. Heady. 1982. Introduction to Agricultural Production Economics. Ibadan University Press. 319 p.

Pingali, P.L. and M.W. Rosegrant. 1994. Confronting the Environmental Consequences of the Green Revolution in Asia. Environment and Production Technology Division, IFPRI. Washington D.C.

Piya, Sujan, A. Kiminami, and H. Yagi. 2011. Sources of Agricultural Productivity Growth in South and Southeast Asia. Trend in Agricultural Economics 4(1):18-29.

Rastogi, P.N. 2002. Sustaining Enterprise Competitiveness -is Human Capital the Answer. 
Human System Management. 19(3), $193-$ 203.

Rekapitulasi Penyuluh Pertanian Berdasarkan Pendidikan. Januari 3, 2012. http://www. deptan.go.id/bppsdmp/images/downloa d/rekappnsdik2010.pdf

Rinsema, W.T. 1986. Pupuk dan Cara Pemupukan. Jakarta: Bhratara Karya Aksara.

Soekartawi. 2003. Teori Ekonomi Produksi dengan Pokok Bahasan Analisis Fungsi Cobb-Douglas. Jakarta: Raja Grafindo Persada.

Suphannachart, W. and P. Warr. 2010. Total Factor Productivity in Thai Agriculture. Working Paper No. 2553/1.

Susilowati, Sri, H. Sumaryanto, dkk. 2008. Arah Perubahan Penguasaan Lahan dan Tenaga Kerja Pertanian. Laporan Akhir Konsorsium Penelitian: Karakteristik Sosial Ekonomi Petani pada Berbagai Agroekosistem. Jakarta: Pusat Analisis Sosial Ekonomi dan Kebijakan Pertanian. Departemen Pertanian.

Swastika, Dewa K.S., J. Wargiono, Soejitno, dan A. Hasanuddin. 2007. Analisis Kebijakan Peningkatan Produksi Padi melalui Efisiensi Pemanfaatan Lahan Sawah di Indonesia. Analisis Kebijakan Pertanian. Volume 5 No. 1, Maret 2007: 36-52.
Thirtle, C.,Lin Lin, J. Piesse. 2003. The Impact of Research-Led Agricultural Productivity Growth on Poverty Reduction in Africa, Asia and Latin America. World Development Vol.31No.12,p 1959-1975.

Todaro, Michael P. 2000. Ekonomi pembangunan di Dunia Ketiga Edisi Tujuh- Jilid 1 (Haris Munandar, Penerjemah). Jakarta: Erlangga.

Undang-Undang RI No. 41 Tahun 2009, tentang Perlindungan Lahan Pertanian Pangan Berkelanjutan. Tambahan Lembaran Negara Republik Indonesia Nomor 5068.

Wooldridge, J.M. 2002. Econometric Analysis of Cross Section and Panel Data. England: MIT Press. Cambridge, Massachusetts.

Wooldridge, J.M.2009. Introductory Econometrics A Modern Approach 4th ed. Canada: South Western-Cengage Learning.

World Bank Report. 2011. Who is Benefiting from Fertilizer Subsidies in Indonesia?. Policy Research Working Paper World Bank East Asia and Pacific Region Poverty Reduction and Economic Management Unit. 